medRxiv preprint doi: https://doi.org/10.1101/2021.07.13.21258405; this version posted July 17, 2021. The copyright holder for this preprint (which was not certified by peer review) is the author/funder, who has granted medRxiv a license to display the preprint in perpetuity.

It is made available under a CC-BY 4.0 International license .

\title{
Rare PSAP variants and possible interaction with $G B A$ in REM sleep behavior disorder
}

\author{
Running Title: Rare PSAP variants in RBD
}

Yuri L. Sosero, MD ${ }^{1,2}$, Eric Yu, MSc ${ }^{1,2}$, Mehrdad A. Estiar, MSc ${ }^{1,2}$, Lynne Krohn, MSc ${ }^{1,2}$, Kheireddin Mufti, MSc ${ }^{1,2}$, Uladzislau Rudakou, MSc ${ }^{1,2}$, Jennifer A. Ruskey, MSc ${ }^{2,3}$, Farnaz Asayesh, MSc ${ }^{2,3}$, Sandra B. Laurent, BTS ${ }^{2,3}$, Dan Spiegelman, MSc ${ }^{2,3}$, Jean-François Trempe, $\mathrm{PhD}^{4}$, Timothy G. Quinnell MD MA FRACP FRCP ${ }^{5}$, Nicholas Oscroft MD FRCP ${ }^{5}$, Isabelle Arnulf, $\mathrm{MD}, \mathrm{PhD}^{6}$, Jacques Y. Montplaisir, $\mathrm{MD}, \mathrm{PhD}^{7,8}$, Jean-François Gagnon, $\mathrm{PhD}^{7,9}$, Alex Desautels, $\mathrm{MD}, \mathrm{PhD}^{7,10}$, Yves Dauvilliers, $\mathrm{MD}, \mathrm{PhD}^{11}$, Gian Luigi Gigli, $\mathrm{MD}^{12,13}$, Mariarosaria Valente, $\mathrm{MD}^{12,13}$, Francesco Janes, $\mathrm{MD}, \mathrm{PhD}^{12}$, Andrea Bernardini, $\mathrm{MD}^{12}$, Karel Sonka, MD, $\mathrm{PhD}^{14}$, David Kemlink, MD, $\mathrm{PhD}^{14}$, Wolfgang Oertel, $\mathrm{MD}^{15}$, Annette Janzen, $\mathrm{MD}^{15}$, Giuseppe Plazzi, MD ${ }^{16,17}$, Elena Antelmi, MD, PhD ${ }^{17,18}$, Francesco Biscarini, $\mathrm{MD}^{19}$, Michela Figorilli, MD, $\mathrm{PhD}^{20}$, Monica Puligheddu, MD, $\mathrm{PhD}^{20}$, Brit Mollenhauer, $\mathrm{MD}^{21,22}$, Claudia Trenkwalder, $\mathrm{MD}^{21,22}$, Friederike Sixel-Döring, MD ${ }^{15,21}$, Valérie Cochen De Cock, MD, PhD ${ }^{23,24}$ Christelle Charley Monaca, $\mathrm{MD}, \mathrm{PhD}^{25}$, Anna Heidbreder, $\mathrm{MD}^{26}$, Luigi Ferini-Strambi, $\mathrm{MD}^{27}$, Femke Dijkstra, $\mathrm{MD}^{28,29,30}$, Mineke Viaene, MD, PhD ${ }^{28,29}$, Beatriz Abril, $\mathrm{MD}^{31}$, Bradley F. Boeve, $\mathrm{MD}^{32}$, Ronald B. Postuma, MD, MSc $\mathrm{C}^{2,3,7}$, Guy A. Rouleau, MD, PhD, FRCPC, FRSC ${ }^{1,2,3}$, Abubaker Ibrahim, MD ${ }^{33}$, Ambra Stefani, $\mathrm{MD}^{33}$, Birgit Högl, $\mathrm{MD}^{33}$, Michele T.M. Hu, MBBS, FRCP, PhD ${ }^{34,35}$, Ziv Gan-Or, $\mathrm{MD}, \mathrm{PhD}^{1,2,3}$.

\section{Affiliations:}

1. Department of Human Genetics, McGill University, Montréal, QC, Canada.

2. Montreal Neurological Institute, McGill University, Montréal, QC, Canada.

3. Department of Neurology and Neurosurgery, McGill University, Montréal, QC, Canada.

4. Department of Pharmacology \& Therapeutics and Centre de Recherche en Biologie Structurale, McGill University, Montréal, Québec, Canada.

5. Royal Papworth Hospital NHS Trust, Cambridge, UK

6. Sleep Disorders Unit, Sorbonne University, Institut du Cerveau - Paris Brain Institute - ICM, Inserm, CNRS, AP-HP, Hôpital de la Pitié Salpêtrière, Paris, France.

7. Centre d'Études Avancées en Médecine du Sommeil, Hôpital du Sacré-Cœur de Montréal, Montréal, QC, Canada.

8. Department of Psychiatry, Université de Montréal, Montréal, QC, Canada.

9. Department of Psychology, Université du Québec à Montréal, Montréal, QC, Canada.

10. Department of Neurosciences, Université de Montréal, Montréal, QC, H3T 1J4, Canada.

11. National Reference Centre for Orphan Diseases, Narcolepsy- Rare hypersomnias, Sleep Unit, Department of Neurology, CHU Montpellier, Institute for Neurosciences of Montpellier INM, Univ Montpellier, INSERM, Montpellier, France

12. Clinical Neurology Unit, Department of Neurosciences, University Hospital of Udine, Udine, Italy.

13. Department of Medicine (DAME), University of Udine, Udine, Italy.

14. Department of Neurology and Centre of Clinical Neuroscience, Charles University, First

Faculty of Medicine and General University Hospital, Prague, Czech Republic.

15. Department of Neurology, Philipps University, Marburg, Germany.

16. Department of Biomedical, Metabolic and Neural Sciences, University of Modena and Reggio

Emilia, Modena, Italy

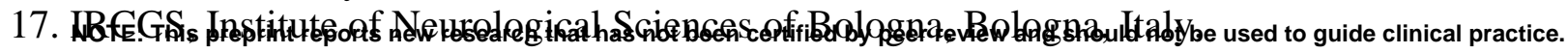


medRxiv preprint doi: https://doi.org/10.1101/2021.07.13.21258405; this version posted July 17, 2021. The copyright holder for this preprint (which was not certified by peer review) is the author/funder, who has granted medRxiv a license to display the preprint in perpetuity.

It is made available under a CC-BY 4.0 International license.

18. Neurology Unit, Movement Disorders Division, Department of Neurosciences, Biomedicine and Movement Sciences, University of Verona, Verona, Italy.

19. Department of Biomedical and Neuromotor Sciences (DIBINEM), Alma Mater Studiorum, University of Bologna, Bologna, Italy.

20. Department of Medical Sciences and Public Health, Sleep Disorder Research Center, University of Cagliari, Cagliari, Italy.

21. Paracelsus-Elena-Klinik, Kassel, Germany.

22. Department of Neurology, University Medical Centre Göttingen, Göttingen, Germany.

23. Sleep and Neurology Unit, Beau Soleil Clinic, Montpellier, France.

24. EuroMov, University of Montpellier, Montpellier, France.

25. University Lille North of France, Department of Clinical Neurophysiology and Sleep Center, CHU Lille, Lille, France.

26. Department of Sleep Medicine and Neuromuscular Disorders, University of Münster, Münster, Germany.

27. Department of Neurological Sciences, Università Vita-Salute San Raffaele, Milan, Italy.

28. Laboratory for Sleep Disorders, St. Dimpna Regional Hospital, Geel, Belgium.

29. Department of Neurology, St. Dimpna Regional Hospital, Geel, Belgium.

30. Department of Neurology, University Hospital Antwerp, Edegem, Antwerp, Belgium.

31. Sleep disorder Unit, Carémeau Hospital, University Hospital of Nîmes, France.

32. Department of Neurology, Mayo Clinic, Rochester, MN, USA.

33. Sleep Disorders Clinic, Department of Neurology, Medical University of Innsbruck, Innsbruck, Austria.

34. Oxford Parkinson's Disease Centre (OPDC), University of Oxford, Oxford, United Kingdom. 35. Nuffield Department of Clinical Neurosciences, University of Oxford, Oxford, United

Kingdom.

\section{Corresponding author:}

Ziv Gan-Or

Montreal Neurological Institute,

McGill University

1033 Pine Avenue, West,

Ludmer Pavilion, room 312

Montréal, QC, H3A 1A1,

Phone: +1-514-398-5845, e-mail: ziv.gan-or@mcgill.ca

Keywords: REM sleep behavior disorder, PSAP, saposin C, Parkinson's disease, GBA, glucocerebrosidase, genetics 
medRxiv preprint doi: https://doi.org/10.1101/2021.07.13.21258405; this version posted July 17, 2021. The copyright holder for this preprint (which was not certified by peer review) is the author/funder, who has granted medRxiv a license to display the preprint in perpetuity.

It is made available under a CC-BY 4.0 International license .

\begin{abstract}
PSAP encodes saposin $\mathrm{C}$, the co-activator of glucocerebrosidase, encoded by GBA. Since $G B A$ mutations are associated with idiopathic/isolated REM sleep behavior disorder (iRBD), a prodromal stage of synucleinopathy, we examined the role of PSAP mutations in iRBD. We fully sequenced PSAP and performed Optimized Sequence Kernel Association Test in 1,113 iRBD patients and 2,324 controls. We identified loss-of-function $(\mathrm{LoF})$ mutations, which are very rare in PSAP, in three iRBD patients and none in controls (uncorrected $p=0.018$ ). Two variants were stop mutations, p.GIn260Ter p.Glu166Ter, and one was an in-frame deletion, p.332_333del. All three mutations have a deleterious effect on saposin C, based on in silico analysis. In addition, the two carriers of p.Glu166Ter and p.332_333del mutations also carried a GBA variant, p.Arg349Ter and p.Glu326Lys, respectively. The co-occurrence of these extremely rare PSAP LoF mutations in two $(0.2 \%) G B A$ variant carriers in the iRBD cohort, is unlikely to occur by chance (estimated co-occurrence in the general population based on gnomAD data is $0.00035 \%$ ). Although none of the three iRBD patients with PSAP LoF mutations have phenoconverted to an overt synucleinopathy at their last follow-up, all manifested initial signs suggestive of motor dysfunction, two were diagnosed with mild cognitive impairment and all showed prodromal clinical markers other than RBD. Their probability of prodromal PD, according to the Movement Disorder Society research criteria was $98 \%$ or more. These results suggest a possible role of PSAP variants in $\mathrm{RRBD}$ and potential genetic interaction with $G B A$, which requires additional studies.
\end{abstract}


medRxiv preprint doi: https://doi.org/10.1101/2021.07.13.21258405; this version posted July 17, 2021. The copyright holder for this preprint (which was not certified by peer review) is the author/funder, who has granted medRxiv a license to display the preprint in perpetuity.

It is made available under a CC-BY 4.0 International license.

\section{Introduction}

Rapid eye movement (REM) sleep behavior disorder (RBD) is characterized by the enactment of dreams during the REM phase of sleep [1]. In its idiopathic/isolated form (iRBD, presenting before the clinical diagnosis of a neurodegenerative disease), it represents a common prodromal stage of synucleinopathies, including Parkinson's disease (PD), dementia with Lewy bodies (DLB) and multiple system atrophy (MSA) [1,2]. Notably, over $80 \%$ of iRBD cases convert to a synucleinopathy within $10-15$ years $[2,3]$. In line with their clinical overlap, iRBD and overt synucleinopathies also share some of their genetic risk factors. For example, iRBD and PD are both associated with $G B A$ variants, which represent one of the most common genetic risk factors for both diseases $[4,5]$. GBA variants display an incomplete penetrance in $\mathrm{RBDD}$ as well as in $\mathrm{PD}[4,5]$, suggesting that other factors, genetic and/or environmental, contribute to the development of these disorders among $G B A$ carriers.

$G B A$ encodes glucocerebrosidase (GCase), a lysosomal hydrolase whose main function is the degradation of glucocerebrosides into ceramide and glucose, although it has additional substrates [5]. To properly function, GCase requires a co-activator, saposin C (sapC) [6]. This protein is one of the four active domains of a protein precursor, prosaposin, encoded by the PSAP gene. After its synthesis, prosaposin is cleaved by cathepsin D (CTSD) into its functional proteins: saposins A, B, C and D [7, 8]. Saposins are lysosomal cofactors that activate enzymes degrading sphingolipids. Mutations in PSAP have been associated with the accumulation of sphingolipids and with different lysosomal storage disorders (LSD). For example, Gaucher's disease, an LSD that is typically caused by biallelic mutations in $G B A$, is also rarely caused by biallelic mutations in the sapC domain of PSAP [7, 9].

Whereas the association of $G B A$ variants with PD is widely accepted, the role played by PSAP in general and sapC specifically in PD remains controversial. Studies in Asian populations suggested an association between PSAP variants and PD [10-14], yet these results did not replicate in Europeans [15-17]. These conflicting results may suggest a possible role played by ethnic differences and/or by 
medRxiv preprint doi: https://doi.org/10.1101/2021.07.13.21258405; this version posted July 17, 2021. The copyright holder for this preprint (which was not certified by peer review) is the author/funder, who has granted medRxiv a license to display the preprint in perpetuity.

It is made available under a CC-BY 4.0 International license .

the extreme rarity of deleterious PSAP variants, reducing their detection in PD. Despite the clinical, biological, and, possibly, genetic links of PSAP with GBA and PD, the role of PSAP in iRBD has not been investigated. Herein, we analyzed a multi-center cohort of 1,113 iRBD patients and 2,324 healthy controls to evaluate a possible association between rare PSAP variants and iRBD.

\section{Methods}

\section{Population}

The current study included 1,113 unrelated iRBD patients and 2,324 unrelated healthy controls of European descent. Details on the cohorts and their recruitment have been previously published [4]. RBD was diagnosed with video polysomnography (vPSG) according to the International Classification of Sleep Disorders, version $2 / 3$ criteria $[18,19]$. About $81 \%$ of the iRBD patients were males $(\mathrm{N}=897)$ and their mean age was $68 \pm 9.4$. Among the controls, $48 \%$ of the participants were males $(\mathrm{N}=1,122)$ and their mean age was $48 \pm 16.7$.

\section{Standard Protocol Approvals, Registrations, and Patient Consents}

All patients signed an informed consent form before entering the study, and the study protocol was approved by the institutional review boards.

\section{Genetic analysis}

The PSAP coding regions were fully sequenced using Molecular Inversion Probes (MIPs) as previously described $[15,20]$. A detailed description of the MIPs library and protocols is available online (https://github.com/gan-orlab/MIP_protocol). Variant annotation was performed with ANNOVAR [21]. The frequency of each variant was extracted from the Genome Aggregation Database (gnomAD) [22]. Post-alignment quality control and variant calling were done using the 
medRxiv preprint doi: https://doi.org/10.1101/2021.07.13.21258405; this version posted July 17, 2021. The copyright holder for this preprint (which was not certified by peer review) is the author/funder, who has granted medRxiv a license to display the preprint in perpetuity.

It is made available under a CC-BY 4.0 International license .

Genome Analysis Toolkit (GATK, v3.8) [23] as previously described [24]. Full code is available at https://github.com/gan-orlab/MIPVar/.

\section{In silico structural analysis}

The impact of the rare variants on the structure and function of the saposin chains was investigated with in silico structural analyses. The atomic coordinates of the human saposin chains B and C were downloaded from the Protein Data Bank [25](ID 1n69 and 1m12, respectively). Images were generated using PyMol v. 2.4.0.

\section{Statistical analysis}

Rare PSAP variants were filtered using a minor allele frequency (MAF) threshold of $<0.01$. To test for rare PSAP variants enrichment in iRBD patients we performed optimized sequence Kernel association test (SKAT-O) for all rare variants and subsets of rare variants. These subsets included nonsynonymous, regulatory, potentially functional (nonsynonymous, frameshift, stop-gain and splicing) and loss-of-function (frameshift, stop-gain and splicing) rare variants. A further subset consisted of variants predicted to have a high deleteriousness probability based on a Combined Annotation Dependent Depletion (CADD) score $\geq 12.37$. SKAT-O analysis was performed using SKAT package in R 3.5.2 [26]. False discovery rate (FDR) correction was applied to correct for multiple comparisons, using Benjamini-Hochberg method with stats package in R 4.0.2.

\section{Results}

We identified 59 rare variants within the PSAP region, of which 15 were nonsynonymous and 3 were loss of function (LoF) variants (Supplementary Table 1). The mean coverage was 568X, and a 
medRxiv preprint doi: https://doi.org/10.1101/2021.07.13.21258405; this version posted July 17, 2021. The copyright holder for this preprint (which was not certified by peer review) is the author/funder, who has granted medRxiv a license to display the preprint in perpetuity.

It is made available under a CC-BY 4.0 International license .

minimum threshold of $30 \mathrm{X}$ was applied for variant quality control. To evaluate if rare PSAP variants are associated with iRBD, we performed SKAT-O comparing iRBD patients and healthy controls. There was a nominally significant enrichment of rare PSAP LoF variants $(p=0.018)$ in iRBD patients. However, after FDR correction, the results lost statistical significance ( $p=0.1$, Table 1$)$. Three out of 1,113 iRBD patients $(0.3 \%)$ carried a rare PSAP LoF variant, while no carriers of LoF variants were found among the controls (0/2324, Supplementary Table 1). In particular, p.Gln260Ter and p.Glu166Ter are both stop variants located, respectively, within the sapB and between sapA and sapB domains, therefore the sapC domain is not translated. The p.332_333del mutation is an in-frame deletion located within the sapC domain.

Given the interplay between sapC and GCase, we examined whether any of these three iRBD patients with PSAP LoF mutations also carry a GBA variant. Furthermore, we tested the presence of GBA copy number variants (CNVs), as was done previously [27]. We found that two of the patients, carrying the p.Glu166Ter and p.332_333del variants, also carried a GBA variant: p.Arg349Ter and p.Glu326Lys, respectively. None carried GBA CNVs. All PSAP and GBA variants were confirmed by Sanger sequencing.

We further examined the frequency of PSAP LoF variants on gnomAD database v2.11 (https://gnomad.broadinstitute.org). None of the LoF variants found in this study have been reported in gnomAD, and the overall frequency of PSAP LoF variants was extremely low, with a total allele count of high-quality LoF variants of 10 in 141,456 individuals $(\sim 0.007 \%$, compared to $\sim 0.3 \%$ in the iRBD cohort). With a frequency of $\sim 5 \%$ in the general European population for $G B A$ variants (based on gnomAD data), the estimated combined carrier frequency of both LoF PSAP variants and GBA variants is $0.00035 \%$, compared to $0.2 \%$ observed in the iRBD cohort, more than a 500 -fold difference.

\section{In silico structural analyses}


medRxiv preprint doi: https://doi.org/10.1101/2021.07.13.21258405; this version posted July 17, 2021. The copyright holder for this preprint (which was not certified by peer review) is the author/funder, who has granted medRxiv a license to display the preprint in perpetuity.

It is made available under a CC-BY 4.0 International license.

To evaluate the impact of the three iRBD-associated variants on the structure and function of the saposin chains we performed in silico analyses. The p.Glu166Ter variant, located between saposin chains $\mathrm{A}$ and $\mathrm{B}$, would result in the termination of expression for chains B-D. The p.GIn260Ter variant is located towards the C-terminus of the sapB domain and would result in the deletion of its C-terminal helix (Figure 1A), as well as in the termination of sapC and sapD translation. This deletion would also unfold sapB and prevent its dimerization, which is critical for binding lipids [28]. Finally, the variant p.332_333del is located in a linker between helices 1 and 2 of sapC (Figure 1B) [29]. This shortened linker would prevent the formation of stabilizing contacts between these helices and thus interfere with its ability to bind membranes and GCase. Therefore, all three variants result in a loss of function of the sapC chain.

\section{Clinical presentation of the iRBD patients with PSAP LoF variants}

The iRBD patient with the p.332_333del PSAP variant was a male in the age range 75-79 who showed minor gait impairment, not quite erect posture, slight global slowness and poverty of spontaneous movements on the neurological examination. His Unified Parkinson's Disease Rating Scale (UPDRS) III [30] score at last follow-up was 3. No cognitive deficits were present (Montreal Cognitive Assessment $($ MoCA $)=29 / 30$ ), yet the patient manifested autonomic symptoms associated with prodromal PD, including constipation, erectile dysfunction and orthostatic hypotension. The risk of prodromal PD according to the Movement Disorder Society (MDS) research criteria [31] at the last follow-up was $1.000(\mathrm{LR}=37452.7$, Table 2).

The iRBD patient with the PSAP p.Glu166Ter variant was a male in the age range 80-84 displaying initial PD motor symptoms, including mild right leg rigidity, slight bilateral slowing of finger tapping movements and stooped posture, with a UPDRS III score of 4 . He was also diagnosed with mild cognitive impairment $(\mathrm{MCI}, \mathrm{MoCA}=23 / 30)$. Furthermore, the patient had some non-motor PD-related symptoms, including significant hyposmia and orthostatic hypotension. His risk for prodromal PD was 0.99 (LR=25600, Table 2). 
medRxiv preprint doi: https://doi.org/10.1101/2021.07.13.21258405; this version posted July 17, 2021. The copyright holder for this preprint (which was not certified by peer review) is the author/funder, who has granted medRxiv a license to display the preprint in perpetuity.

It is made available under a CC-BY 4.0 International license .

Finally, the iRBD patient with the PSAP p.Gln260Ter variant was a male in the age range 6064 showing some signs of motor impairment, including mild asymmetric finger tapping and top tapping bradykinesia. His UPDRS III score was 3 and he was diagnosed with MCI (MoCA = 26/30). He displayed severe hyposmia, while no autonomic symptoms were present. His risk of prodromal PD at his last follow-up was 0.98 ( $\mathrm{LR}=4072$, Table 2).

\section{Discussion}

In this study, we found three iRBD patients with extremely rare PSAP LoF variants, not reported on gnomAD, while no controls were found with LoF variants. Interestingly, two of the three PSAP LoF variant carriers also carried a GBA variant. While the enrichment of rare PSAP LoF variants in iRBD was only nominally significant, given their rarity it is plausible that this reflects a real association. Furthermore, assuming that in the general European population the carrier frequency of $G B A$ variants is about $5 \%$, and the carrier frequency of LoF variants (based on gnomAD) is about $0.007 \%$, the probability to carry both a GBA variant and a PSAP LoF variant is $0.00035 \%$. In the iRBD cohort, the carrier frequency of both was $\sim 0.2 \%$, suggesting that this is likely not due to chance alone. The deleteriousness of the three PSAP LoF variants was further exemplified by structural analyses (Figure 1A and 1B). All iRBD patients met the MDS criteria for probable prodromal PD (Table 2).

Although the role of PSAP in iRBD and in synucleinopathies in general is still controversial, this study provides the first evidence for a possible role of PSAP variants in iRBD. The lack of a statistically significant enrichment in $\mathrm{RBBD}$ patients after correction for multiple comparisons can be explained by the extreme rarity of PSAP variants, resulting in insufficient power. The Residual Variation Intolerance Score (RVIS) of PSAP is -1 , putting it in the top $8.47 \%$ of genes in the human genome which are intolerant to genetic variance, especially for LoF variance (FDR corrected $p=0.00037$ for the observed vs. expected number of LoF variants - http://genicintolerance.org/Search?query=psap). 
medRxiv preprint doi: https://doi.org/10.1101/2021.07.13.21258405; this version posted July 17, 2021. The copyright holder for this preprint (which was not certified by peer review) is the author/funder, who has granted medRxiv a license to display the preprint in perpetuity.

It is made available under a CC-BY 4.0 International license .

Two iRBD carriers of PSAP LoF variants were also carriers of a $G B A$ variant. Given the incomplete penetrance of $G B A$ in iRBD, the presence of potentially pathogenic variants in PSAP among GBA carriers may suggest oligogenic inheritance and that PSAP variants might act as genetic modifiers of risk in GBA-iRBD. This is in line with the biological link between sapC and GCase [6, 9]. In particular, it is possible that an impairment of the sapC-mediated activation of GCase contributes to an increased risk to develop iRBD in $G B A$ variant carriers. These hypotheses require additional genetic and functional studies. We cannot rule out that the co-occurrence of $G B A$ and PSAP variants is a coincidence, due to chance alone. However, the fact that two out of three extremely rare PSAP LoF variant carriers also carried a $G B A$ mutation makes a coincidental association less likely.

It is still unclear whether PSAP mutations alone can increase the risk of iRBD or PD. It is possible that $\mathrm{LoF}$ of sapC, as seen in our patient with the p.332_333del mutation, will result in reduced activation of GCase and be an independent risk factor. On the other hand, it is also possible that PSAP variants might lead to iRBD through mechanisms independent of $G B A$. A possible mechanism can be due to an impairment of CTSD and progranulin (PGRN) activity, as previously hypothesized in PD [8]. PSAP, CTSD and PGRN interact in a network involved in lysosomal homeostasis and clearance of alpha-synuclein. PSAP dysfunction might lead to decreased transport of PGRN into the lysosome, reduction of the pro-CTSD conversion into active CTSD, and consequently to impaired lysosomal trafficking and degradation of deleterious or overrepresented proteins, such as alphasynuclein [8].

This study has several limitations. Age and sex differed between patients and controls. However, this difference would generally lead to false negative results (as young mutation carriers still would not develop the disease), and is, therefore, less likely to affect our results, as no carriers were found in the controls. Although this study was performed in the largest genetic cohort of iRBD patients worldwide, the sample size may still be insufficient to detect extremely rare variants in PSAP. Finally, we were able to find PSAP LoF variants, different from each other, in only 3 iRBD patients. 
medRxiv preprint doi: https://doi.org/10.1101/2021.07.13.21258405; this version posted July 17, 2021. The copyright holder for this preprint (which was not certified by peer review) is the author/funder, who has granted medRxiv a license to display the preprint in perpetuity.

It is made available under a CC-BY 4.0 International license .

However, the absence of such variants in the $\sim$ twofold larger control group and in the $\sim 140$-fold larger gnomAD control population suggests that this finding might not be random.

Further studies in larger cohorts and functional analyses will be required to clarify the role of PSAP variants in iRBD and alpha-synuclein physiopathology. In addition, studies in other populations, such as East Asians, where PSAP variants have already been proposed as PD risk factors [10-14], will be necessary to further explore differences in the genetic underpinnings of synucleinopathies between different ethnic groups.

\section{Acknowledgments}

We wholeheartedly thank the participants in this study. This work was financially supported by the Michael J. Fox Foundation, Parkinson's Society Canada, the Canadian Consortium on Neurodegeneration in Aging (CCNA), and the Canada First Research Excellence Fund (CFREF), awarded to McGill University for the Healthy Brains for Healthy Lives (HBHL) program. JFG holds a Canada Research Chair in Cognitive Decline in Pathological Aging. GAR holds a Canada Research Chair in Genetics of the Nervous System and the Wilder Penfield Chair in Neurosciences. WO is Hertie Senior Research Professor, supported by the Charitable Hertie Foundation, Frankfurt/Main, Germany. The Oxford Discovery study was funded by the Monument Trust Discovery Award from Parkinson's UK and supported by the National Institute for Health Research (NIHR) Oxford Biomedical Research Centre based at Oxford University Hospitals NHS Trust and University of Oxford, the NIHR Clinical Research Network and the Dementias and Neurodegenerative Diseases Research Network (DeNDRoN). ZGO is supported by the Fonds de recherche du Québec - Santé (FRQS) Chercheurs-boursiers award, and is a William Dawson Scholar. We thank Daniel Rochefort, Helene Catoire and Vessela Zaharieva for their assistance.

\section{Relevant conflicts of interest/financial disclosures}


medRxiv preprint doi: https://doi.org/10.1101/2021.07.13.21258405; this version posted July 17, 2021. The copyright holder for this preprint (which was not certified by peer review) is the author/funder, who has granted medRxiv a license to display the preprint in perpetuity.

It is made available under a CC-BY 4.0 International license.

ZGO has received consulting fees from Lysosomal Therapeutics Inc., Idorsia, Prevail Therapeutics, Denali, Ono Therapeutics, Neuron23, Handl Therapeutics, Bial Biotech Inc., Deerfield and Guidepoint, Lighthouse and Inception Sciences (now Ventus). None of these companies were involved in any parts of preparing, drafting and publishing this study. Other authors have no additional disclosures to report. YD received honoraria for speaking and board engagements from UCB Pharma, Jazz, Bioprojet, Theranexus, Takeda, Idorsia. 
medRxiv preprint doi: https://doi.org/10.1101/2021.07.13.21258405; this version posted July 17, 2021. The copyright holder for this preprint (which was not certified by peer review) is the author/funder, who has granted medRxiv a license to display the preprint in perpetuity.

It is made available under a CC-BY 4.0 International license .

\section{References}

[1] Krohn L, Wu RYJ, Heilbron K, Ruskey JA, Laurent SB, Blauwendraat C, Alam A, Arnulf I, Hu MTM, Dauvilliers Y, Hogl B, Toft M, Bjornara KA, Stefani A, Holzknecht E, Monaca CC, Abril B, Plazzi G, Antelmi E, Ferini-Strambi L, Young P, Heidbreder A, Cochen De Cock V, Mollenhauer B, Sixel-Doring F, Trenkwalder C, Sonka K, Kemlink D, Figorilli M, Puligheddu M, Dijkstra F, Viaene M, Oertel W, Toffoli M, Gigli GL, Valente M, Gagnon JF, Nalls MA, Singleton AB, andMe Research T, Desautels A, Montplaisir JY, Cannon P, Ross OA, Boeve BF, Dupre N, Fon EA, Postuma RB, Pihlstrom L, Rouleau GA, Gan-Or Z (2020) Fine-Mapping of SNCA in Rapid Eye Movement Sleep Behavior Disorder and Overt Synucleinopathies. Ann Neurol 87, 584-598.

[2] Mufti K, Rudakou U, Yu E, Krohn L, Ruskey JA, Asayesh F, Laurent SB, Spiegelman D, Arnulf I, Hu MTM, Montplaisir JY, Gagnon JF, Desautels A, Dauvilliers Y, Gigli GL, Valente M, Janes F, Hogl B, Stefani A, Holzknecht E, Sonka K, Kemlink D, Oertel W, Janzen A, Plazzi G, Antelmi E, Figorilli M, Puligheddu M, Mollenhauer B, Trenkwalder C, Sixel-Doring F, Cochen De Cock V, Monaca CC, Heidbreder A, Ferini-Strambi L, Dijkstra F, Viaene M, Abril B, Boeve BF, Postuma RB, Rouleau GA, Gan-Or Z (2021) Comprehensive Analysis of Familial Parkinsonism Genes in Rapid-Eye-Movement Sleep Behavior Disorder. Mov Disord 36, 235-240.

[3] Postuma RB, Gagnon JF, Bertrand JA, Genier Marchand D, Montplaisir JY (2015) Parkinson risk in idiopathic REM sleep behavior disorder: preparing for neuroprotective trials. Neurology 84, $1104-$ 1113.

[4] Krohn L, Ruskey JA, Rudakou U, Leveille E, Asayesh F, Hu MTM, Arnulf I, Dauvilliers Y, Hogl B, Stefani A, Monaca CC, Abril B, Plazzi G, Antelmi E, Ferini-Strambi L, Heidbreder A, Boeve BF, Espay AJ, De Cock VC, Mollenhauer B, Sixel-Doring F, Trenkwalder C, Sonka K, Kemlink D, Figorilli M, Puligheddu M, Dijkstra F, Viaene M, Oertel W, Toffoli M, Gigli GL, Valente M, Gagnon JF, Desautels A, Montplaisir JY, Postuma RB, Rouleau GA, Gan-Or Z (2020) GBA variants in REM sleep behavior disorder: A multicenter study. Neurology 95, e1008-e1016.

[5] Gan-Or Z, Amshalom I, Kilarski LL, Bar-Shira A, Gana-Weisz M, Mirelman A, Marder K, Bressman S, Giladi N, Orr-Urtreger A (2015) Differential effects of severe vs mild GBA mutations on Parkinson disease. Neurology 84, 880-887.

[6] Sun Y, Qi X, Grabowski GA (2003) Saposin C is required for normal resistance of acid betaglucosidase to proteolytic degradation. J Biol Chem 278, 31918-31923.

[7] Kishimoto Y, Hiraiwa M, O'Brien JS (1992) Saposins: structure, function, distribution, and molecular genetics. J Lipid Res 33, 1255-1267.

[8] Tayebi N, Lopez G, Do J, Sidransky E (2020) Pro-cathepsin D, Prosaposin, and Progranulin: Lysosomal Networks in Parkinsonism. Trends Mol Med 26, 913-923.

[9] Yap TL, Gruschus JM, Velayati A, Sidransky E, Lee JC (2013) Saposin C protects glucocerebrosidase against alpha-synuclein inhibition. Biochemistry 52, 7161-7163.

[10] Oji Y, Hatano T, Ueno SI, Funayama M, Ishikawa KI, Okuzumi A, Noda S, Sato S, Satake W, Toda T, Li Y, Hino-Takai T, Kakuta S, Tsunemi T, Yoshino H, Nishioka K, Hattori T, Mizutani Y, Mutoh T, Yokochi F, Ichinose Y, Koh K, Shindo K, Takiyama Y, Hamaguchi T, Yamada M, Farrer MJ, Uchiyama Y, Akamatsu W, Wu YR, Matsuda J, Hattori N (2020) Variants in saposin D domain of prosaposin gene linked to Parkinson's disease. Brain 143, 1190-1205.

[11] Zhao YW, Pan HX, Zeng Q, Fang ZH, Liu ZH, Wang Y, Jiang L, He R, Zhou X, Zhou YJ, Xu Q, Sun QY, Li B, Zhao G, Yang Y, Hu YC, Chen YS, Du J, Lei LF, Zhang HN, Wang CY, Yan XX, Shen L, Jiang H, Li JC, Tang BS, Tan JQ, Guo JF (2021) PSAP variants in Parkinson's disease: a large cohort study in Chinese mainland population. Brain 144, e25.

[12] Chao YX, Lee B, Ng EY, Lian MM, Chew EGY, Tandiono M, Li Z, Khor CC, Kumar P, Tan LCS, Foo JN, Tan EK (2021) Association analysis of PSAP variants in Parkinson's disease patients. Brain 144, e9.

[13] Lin ZH, Ruan Y, Xue NJ, Fang Y, Pu JL, Zhang BR (2021) PSAP intronic variants around saposin D domain and Parkinson's disease. Brain 144, e3. 
medRxiv preprint doi: https://doi.org/10.1101/2021.07.13.21258405; this version posted July 17, 2021. The copyright holder for this preprint (which was not certified by peer review) is the author/funder, who has granted medRxiv a license to display the preprint in perpetuity.

It is made available under a CC-BY 4.0 International license .

[14] Chen YP, Gu XJ, Ou RW, Zhang LY, Hou YB, Liu KC, Cao B, Wei QQ, Song W, Zhao B, Wu Y, Cheng JQ, Shang HF (2021) Genetic Analysis of Prosaposin, the Lysosomal Storage Disorder Gene in Parkinson's Disease. Mol Neurobiol 58, 1583-1592.

[15] Ouled Amar Bencheikh B, Leveille E, Ruskey JA, Spiegelman D, Liong C, Fon EA, Rouleau GA, Dauvilliers Y, Dupre N, Alcalay RN, Gan-Or Z (2018) Sequencing of the GBA coactivator, Saposin C, in Parkinson disease. Neurobiol Aging 72, 187 e181-187 e183.

[16] Sosero YL, Bandres-Ciga S, Hassin-Baer S, Alcalay RN, Gan-Or Z (2020) Lack of evidence for genetic association of saposins A, B, C and D with Parkinson's disease. Brain 143, e72.

[17] Facchi D, Rimoldi V, Straniero L, Paraboschi EM, Soldà G, Zecchinelli AL, Cilia R, Duga S, Pezzoli G, Asselta R (2020) Saposin D variants are not a common cause of familial Parkinson's disease among Italians. Brain 143, e71.

[18] Thorpy MJ (2012) Classification of sleep disorders. Neurotherapeutics 9, 687-701.

[19] Stefani A, Hogl B (2019) Diagnostic Criteria, Differential Diagnosis, and Treatment of Minor Motor Activity and Less Well-Known Movement Disorders of Sleep. Curr Treat Options Neurol 21, 1.

[20] Ruskey JA, Greenbaum L, Roncière L, Alam A, Spiegelman D, Liong C, Levy OA, Waters C, Fahn S, Marder KS, Chung W, Yahalom G, Israeli-Korn S, Livneh V, Fay-Karmon T, Alcalay RN, Hassin-Baer S, Gan-Or Z (2019) Increased yield of full GBA sequencing in Ashkenazi Jews with Parkinson's disease. Eur J Med Genet 62, 65-69.

[21] Wang K, Li M, Hakonarson H (2010) ANNOVAR: functional annotation of genetic variants from highthroughput sequencing data. Nucleic Acids Res 38, e164.

[22] Lek M, Karczewski KJ, Minikel EV, Samocha KE, Banks E, Fennell T, O'Donnell-Luria AH, Ware JS, Hill AJ, Cummings BB, Tukiainen T, Birnbaum DP, Kosmicki JA, Duncan LE, Estrada K, Zhao F, Zou J, Pierce-Hoffman E, Berghout J, Cooper DN, Deflaux N, DePristo M, Do R, Flannick J, Fromer M, Gauthier L, Goldstein J, Gupta N, Howrigan D, Kiezun A, Kurki MI, Moonshine AL, Natarajan P, Orozco L, Peloso GM, Poplin R, Rivas MA, Ruano-Rubio V, Rose SA, Ruderfer DM, Shakir K, Stenson PD, Stevens C, Thomas BP, Tiao G, Tusie-Luna MT, Weisburd B, Won HH, Yu D, Altshuler DM, Ardissino D, Boehnke M, Danesh J, Donnelly S, Elosua R, Florez JC, Gabriel SB, Getz G, Glatt SJ, Hultman CM, Kathiresan S, Laakso M, McCarroll S, McCarthy MI, McGovern D, McPherson R, Neale BM, Palotie A, Purcell SM, Saleheen D, Scharf JM, Sklar P, Sullivan PF, Tuomilehto J, Tsuang MT, Watkins HC, Wilson JG, Daly MJ, MacArthur DG, Exome Aggregation C (2016) Analysis of proteincoding genetic variation in 60,706 humans. Nature 536, 285-291.

[23] McKenna A, Hanna M, Banks E, Sivachenko A, Cibulskis K, Kernytsky A, Garimella K, Altshuler D, Gabriel S, Daly M, DePristo MA (2010) The Genome Analysis Toolkit: a MapReduce framework for analyzing next-generation DNA sequencing data. Genome Res 20, 1297-1303.

[24] Rudakou U, Ruskey JA, Krohn L, Laurent SB, Spiegelman D, Greenbaum L, Yahalom G, Desautels A, Montplaisir JY, Fahn S, Waters CH, Levy O, Kehoe CM, Narayan S, Dauvilliers Y, Dupre N, HassinBaer S, Alcalay RN, Rouleau GA, Fon EA, Gan-Or Z (2020) Analysis of common and rare VPS13C variants in late-onset Parkinson disease. Neurol Genet 6, 385.

[25] Berman HM, Westbrook J, Feng Z, Gilliland G, Bhat TN, Weissig H, Shindyalov IN, Bourne PE (2000) The Protein Data Bank. Nucleic Acids Res 28, 235-242.

[26] Wu MC, Lee S, Cai T, Li Y, Boehnke M, Lin X (2011) Rare-variant association testing for sequencing data with the sequence kernel association test. Am J Hum Genet 89, 82-93.

[27] Yu E, Rudakou U, Krohn L, Mufti K, Ruskey JA, Asayesh F, Estiar MA, Spiegelman D, Surface M, Fahn S, Waters CH, Greenbaum L, Espay AJ, Dauvilliers Y, Dupré N, Rouleau GA, Hassin-Baer S, Fon EA, Alcalay RN, Gan-Or Z (2021) Analysis of Heterozygous PRKN Variants and Copy-Number Variations in Parkinson's Disease. Mov Disord 36, 178-187.

[28] Ahn VE, Faull KF, Whitelegge JP, Fluharty AL, Prive GG (2003) Crystal structure of saposin B reveals a dimeric shell for lipid binding. Proc Natl Acad Sci U S A 100, 38-43.

[29] de Alba E, Weiler S, Tjandra N (2003) Solution structure of human saposin C: pH-dependent interaction with phospholipid vesicles. Biochemistry 42, 14729-14740.

[30] Goetz CG, Fahn S, Martinez-Martin P, Poewe W, Sampaio C, Stebbins GT, Stern MB, Tilley BC, Dodel $R$, Dubois $B$, Holloway R, Jankovic J, Kulisevsky J, Lang AE, Lees A, Leurgans S, LeWitt PA, Nyenhuis D, Olanow CW, Rascol O, Schrag A, Teresi JA, Van Hilten JJ, LaPelle N (2007) Movement Disorder 
medRxiv preprint doi: https://doi.org/10.1101/2021.07.13.21258405; this version posted July 17,2021 . The copyright holder for this preprint (which was not certified by peer review) is the author/funder, who has granted medRxiv a license to display the preprint in perpetuity.

It is made available under a CC-BY 4.0 International license.

Society-sponsored revision of the Unified Parkinson's Disease Rating Scale (MDS-UPDRS): Process, format, and clinimetric testing plan. Mov Disord 22, 41-47.

[31] Berg D, Postuma RB, Adler CH, Bloem BR, Chan P, Dubois B, Gasser T, Goetz CG, Halliday G, Joseph L, Lang AE, Liepelt-Scarfone I, Litvan I, Marek K, Obeso J, Oertel W, Olanow CW, Poewe W, Stern M, Deuschl G (2015) MDS research criteria for prodromal Parkinson's disease. Mov Disord 30, 16001611. 
medRxiv preprint doi: https://doi.org/10.1101/2021.07.13.21258405; this version posted July 17,2021 . The copyright holder for this preprint (which was not certified by peer review) is the author/funder, who has granted medRxiv a license to display the preprint in perpetuity.

It is made available under a CC-BY 4.0 International license.

Table 1 - Optimized sequence Kernel association test (SKAT-O) for PSAP rare variants

\begin{tabular}{ccc}
\hline Rare variant subset & P.value & P.adj \\
\hline CADD & 0.034792187 & 0.1043766 \\
\hline Encode & 0.286264029 & 0.3021955 \\
\hline Func & 0.302195501 & 0.3021955 \\
\hline LoF & 0.017929809 & 0.1043766 \\
\hline NS & 0.052448772 & 0.1048975 \\
\hline All & 0.246565484 & 0.3021955 \\
\hline
\end{tabular}

CADD: Variants selected based on a Combined Annotation Dependent Depletion threshold >12.37; Encode: variants in regulatory elements; Func: potentially functional variants; LoF; loss of function variants; NS: nonsynonymous; All: all rare variants; P.adj: corrected p-value for multiple comparisons using false discovery rate 
medRxiv preprint doi: https://doi.org/10.1101/2021.07.13.21258405; this version posted July 17,2021 . The copyright holder for this preprint (which was not certified by peer review) is the author/funder, who has granted medRxiv a license to display the preprint in perpetuity.

It is made available under a CC-BY 4.0 International license .

Table 2 - Clinical data at last follow-up of iRBD patients carrying PSAP rare variants

\begin{tabular}{|c|c|c|c|}
\hline $\begin{array}{l}\text { PSAP LoF rare } \\
\text { variants }\end{array}$ & p.332_333del & p.Glu166Ter & p.GIn260Ter \\
\hline$G B A$ variants & p.Glu326Lys & p.Arg349Ter & No \\
\hline Sex & Male & Male & Male \\
\hline AAD range & $75-79$ & $80-84$ & $60-64$ \\
\hline Disease duration & $>13$ years & $>2$ years & $>5$ years \\
\hline Tremor & No & No & No \\
\hline Hypokinesia & No & Initial signs & No \\
\hline Bradykinesia & No & Initial signs & Initial signs \\
\hline Postural instability & No & No & No \\
\hline Cognitive symptoms & No & Yes & Yes \\
\hline Psychiatric symptoms & No & No & No \\
\hline Hyposmia & No & Yes & Yes \\
\hline $\begin{array}{l}\text { Orthostatic } \\
\text { hypotension }\end{array}$ & Yes & Yes & $\begin{array}{l}\text { Dizziness standing up } \\
\text { (negative tilt test) }\end{array}$ \\
\hline Constipation & Yes & No & No \\
\hline Urinary dysfunction & No & No & No \\
\hline Erectile dysfunction & Yes & No & No \\
\hline Imaging signs & $\begin{array}{l}\text { Substantia nigra } \\
\text { hyperechogenicity on the right } \\
\text { side }\end{array}$ & I & / \\
\hline Risk prodromal PD & $0.98(288)-1(37458)$ & $\begin{array}{c}0.96(551)-0.99 \\
\quad(25600)\end{array}$ & $\begin{array}{c}0.53(88)-0.98 \\
\quad(4072)\end{array}$ \\
\hline MDS-UPDRS III & 3 & 4 & 3 \\
\hline Smoker & Yes (ex-smoker) & Yes (ex-smoker) & Yes (ex-smoker) \\
\hline
\end{tabular}

LoF: loss of function variant; AAD range: age at diagnosis range; Disease duration: disease duration from age at diagnosis to last follow-up; Risk prodromal PD: risk for prodromal Parkinson's disease according to the Movement Disorder Society (MDS) criteria, not considering iRBD (values on the left) and considering iRBD (values on the right). Values in parentheses indicate the likelihood ratios; MDS-UPDRS: Movement Disorder Society - Unified Parkinson's Disease Rating Scale 
medRxiv preprint doi: https://doi.org/10.1101/2021.07.13.21258405; this version posted July 17, 2021. The copyright holder for this preprint (which was not certified by peer review) is the author/funder, who has granted medRxiv a license to display the preprint in perpetuity.

It is made available under a CC-BY 4.0 International license .

Figure 1 - Structural analysis of the saposin B and C domains

\section{A

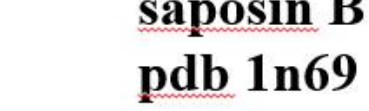

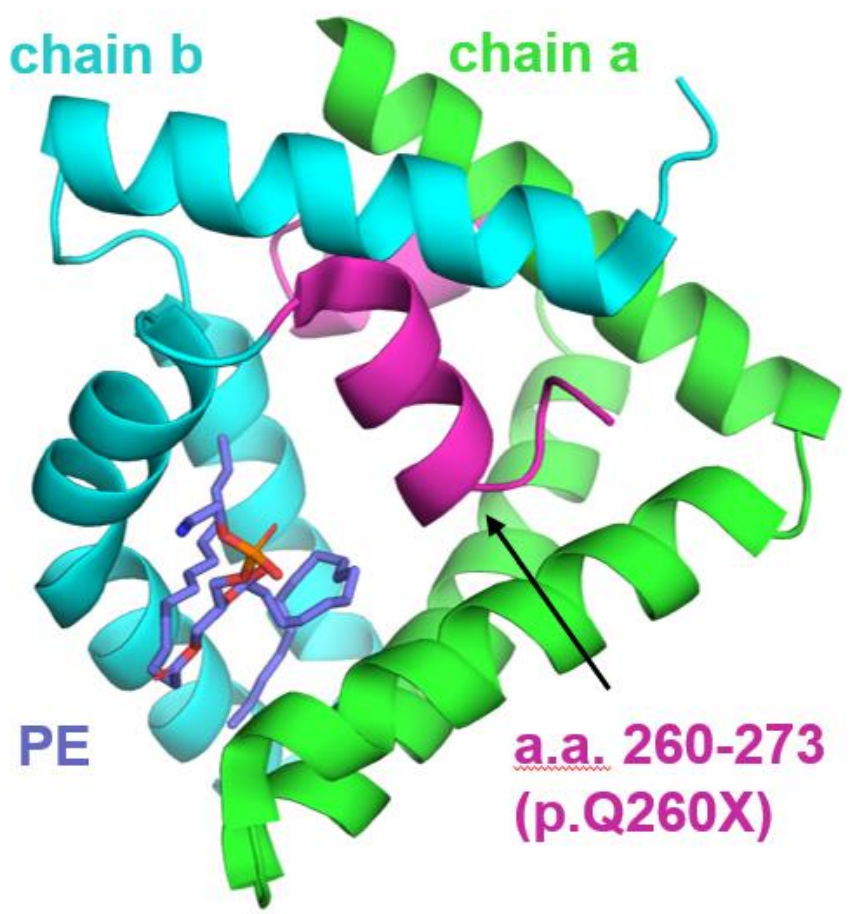

\section{B $\operatorname{saposin} \mathrm{C}$ pdb $1 \mathrm{~m} 12$}

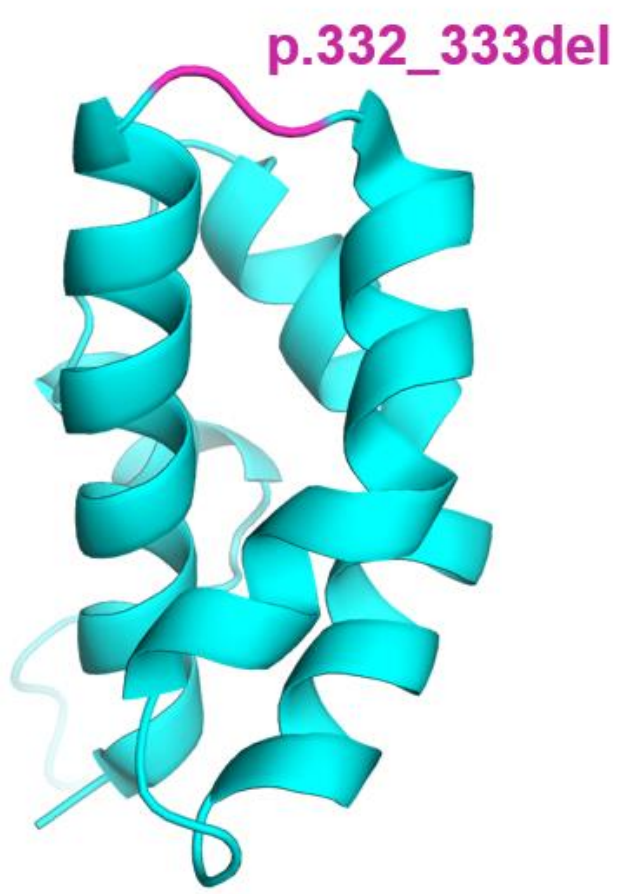

(A) Crystal structure of the saposin B dimer (green and cyan, pdb 1n69). A bound phosphatidylethanolamine (PE) is shown in violet. The C-terminal helix (a.a. 260-273) deleted in the p.Gln260Ter variant is shown in magenta. (B) Solution NMR structure of the human saposin-C domain (cyan, pdb 1m12). In-frame deletion of amino acids Asn332 and Lys333 is shown in magenta. 